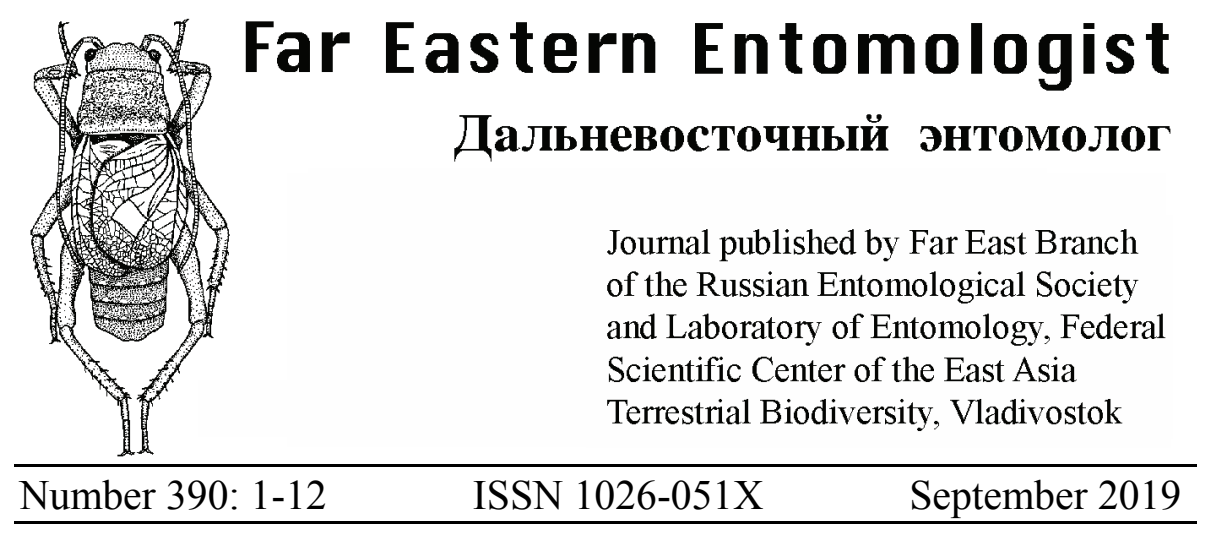

https://doi.org/10.25221/fee.390.1

http://zoobank.org/References/0783F58A-3EF7-458A-B631-DF33481F48D6

\title{
A NEW GENUS AND NEW SPECIES OF BRISTLETAILS OF THE FAMILY NICOLETIIDAE (ZYGENTOMA) FROM SOUTH CHINA
}

\section{G. Kaplin}

1) All-Russian Institute of Plant Protection, Podbelskogo 3, St. PetersburgPushkin,189620,Russia.E-mail: ctenolepisma@mail.ru

Summary. A new genus Allobrinckina gen. n. (type species: A. belousovi sp. n.) is described from Yunnan province (South China). Pretarsus of the new genus with two claws and a slightly convex support oval platform with 5-6 transverse ribs in both sexes. Apical part of glossae divided into two lobes in male and female. Posterior notch of urotergite $\mathrm{X}$ in female with $1+1$ long and robust posterolateral apical bifurcate macrochaetae. Urotergite $X$ of male with lateral pigmented pegs and with two longitudinal rows of simple macrochaetae near the inner parts of pegs areas. Male pedicellus with well-developed finger-shaped apophyses and fovea.

Key words: bristletails, Zygentoma, Nicoletiinae, taxonomy, Coletinia genusgroup, new taxa, Yunnan.

В. Г. Каплин. Новый род и новый вид щетинохвосток семейства Nicoletiidae (Zygentoma) из Южного Китая // Дальневосточный энтомолог. 2019. N 390. C. 1-12.

Резюме. Из южнокитайской провинции Юньнань описан новый род щетинохвосток Allobrinckina gen. n. (типовой вид: A. belousovi sp. n.). Предлапка у нового рода с двумя коготками и слегка выпуклой овальной опорной площадкой 
с 5-6 поперечными ребрами у обоих полов. Глоссы в апикальной части разделены на две лопасти у самца и самки. Углы задней выемки X тергита брюшка самки с $1+1$ длинными двухвершинными макрохетами. $\mathrm{X}$ тергит брюшка самца с боковыми пигментированными колышками и двумя продольными рядами простых макрохет вблизи внутренних краев полей с колышками. Ножка усиков самцов с хорошо развитым пальцевидным отростком и боковой овальной сенсорной ямкой.

\section{INTRODUCTION}

The new genus belongs to the family Nicoletiidae Lubbock, 1873, subfamily Coletiniinae Mendes, 1988, Coletinia genus-group (Mendes, 1988, 1994; Smith, 1998), which consists of five genera: Coletinia Wygodzinsky, 1980 [about 21 species mainly from Mediterranean region] (Wygodzinsky, 1980; Molero et al., 2013); Lepidina Silvestry, 1949 [two species from Africa and Melanesia] (Paclt, 1974); Pseudobrinckina Mendes, 2002 [one species from Thailand] (Mendes, 2002a), Squamatinia Mendes, 2012 [one species from Portugal] (Reboleira et al., 2012), and Lepidospora Escherich, 1905 with three subgenera: Lepidospora s. str. [about 28 species from Mediterranean region, Africa, Arabia, Indostan, Indochine, Indonesia] (Mendes, 2002b; Kaplin, 2012; Espinasa \& Mendes, 2013), Brinckina Wygodzinsky, 1955 [about 8 species from the Democratic Republic of Congo, Kenya, South Africa, China, Afghanistan, Australia, maybe Papua New Guinea] (Wygodzinsky, 1955; Smith, 1998; Smith \& McRae, 2016) and Brinckiletinia Tahami, Molero et Gaju, 2018 [one species from Iran] (Tahami et al., 2018). First urosternite of bristletails of the Coletinia genus-group divided into one sternite and two coxites, urosternites II-VII in female or II-VIII in male entire; urocoxites VIII, IX in female and IX in male free. Stylets on II-IX or III-IX (Lepidina), eversible vesicles on II-VI or III-VI (Lepidina), pseudovesicles on VII urosternites; pretarsus with empodium, except Pseudobrinckina.

\section{MATERIALS AND METHODS}

Examination of the bristletails collected by the authors in $75 \%$ alcohol in environs of Lijiang (China, NW of Yunnan province) has revealed one male and two females of a new genus and new species of the subfamily Nicoletiinae; its descriptions are given below. Holotype (male) and one paratype (female) were dissected and mounted on glass microscope slides in the Berlese fluid. Figures were made using microscope and drawing tool. Types of the new species are deposited in the collection of the All-Russian Institute of Plant Protection (VIZR), St. Petersburg-Pushkin.

\section{DESCRIPTION OF NEW TAXA}

Family Nicoletiidae Lubbock, 1873

Subfamily Coletiniinae Mendes, 1988 
Genus Allobrinckina Kaplin, gen. n.

http://zoobank.org/NomenclaturalActs/096CFF13-AD62-4822-9317-D5D104FA31E0

Type species: Allobrinckina belousovi Kaplin, sp. n., designated here.

DESCRIPTION. Body relatively long, devoid of pigment with typical multiradiate scales on body and coxae of legs, lacking on head. Antennae slightly shorter than body. Pedicellus of male with relatively long finger-shaped apophyses on medial face and well-developed fovea (Figs 1, 13). Mandibles strong with welldeveloped molar, incisor region with 7 incisives (Fig 3). Maxillae of usual form, galea with two apical conules, lacinia with pectinate prostheca (Figs 4, 5). Ultimate palpomere of maxillary palps with six papillae of usual form. Ultimate palpomere of labial palps with six papillae of usual type. Apical parts of glossae divided into two lobes (Figs 15, 23).

Thorax practically not wider than the abdomen. Posterior margin of all thoracic tergites with $1+1$ submedian and $2+2$ sublateral macrochaetae, first of lateral macrochaetae of thoracic tergites very long, about 0.4 their length (Fig 22).

Legs quite elongate. Coxae and femora of male and female widened. Tarsi with two rows of stout macrochaetae along its ventral surface (Fig 6). Praetarsus with two strong claws covered by microtrichia on their basal half, without medial empodial claw. Between claws instead of the empodium there is a slightly convex support oval platform with 5-6 transverse ribs in both sexes (Fig 8).

Urotergites I-IX with $1+1$ submedian and several sublateral and lateral macrochaetae (Figs 9, 10). Urotergite X trapezoidal with well-developed rounded posterior emargination. Posterolateral corners of urotergite $X$ of female with $1+1$ long apical bifurcate macrochaetae (Fig 12). Urotergite X of male with $16+17$ lateral pegs and with simple macrochaetae near the inner part of pegs areas, several of them form two longitudinal rows (Fig 11).

Urosternite I divided into a median sternite and two lateral coxites (Fig 16). Urosternites II-VII in female and II-VIII in male entire, styli on urosternites II-IX, $1+$ I eversible vesicles on urosternites II-VI and $1+1$ pseudovesicles on urosternite VII (Figs 17-19, 21, 25). Posterior angle of sternite I acute (Fig 16). Posterior part of urosternites II-VII with two pairs of relatively long and thin apically bifurcate setae between eversible vesicles. Subgenital plate of female well-developed, suboval (Fig 24).

Parameres long reach to about 0.55 the length of styli, about six times longer than wide (Fig 21). First basal divisions of cerci of male with $1+1$ preserved inner pegs. Ovipositor slightly longer than styli IX, gonapophyses with 11-12 divisions (Fig 25).

RELATIONSHIPS. Allobrinckina gen. n. as Pseudobrinckina Mendes, 2002 from Thailand devoid of empodium, with scales on body and coxae, lacking on head. Allobrinckina gen. $\mathrm{n}$. is the first described Coletiinae and Nicoletiidae with a slightly convex support oval platform with 5-6 transverse ribs between claws of pretarsus in both sexes. Posterior notch of urotergite X in female of Pseudobrinckina with $2+2$, Allobrinckina gen. $n$. with $1+1$ long and robust posterolateral macrochaetae. Apical part of glossae in female of Pseudobrinckina not divided and in 


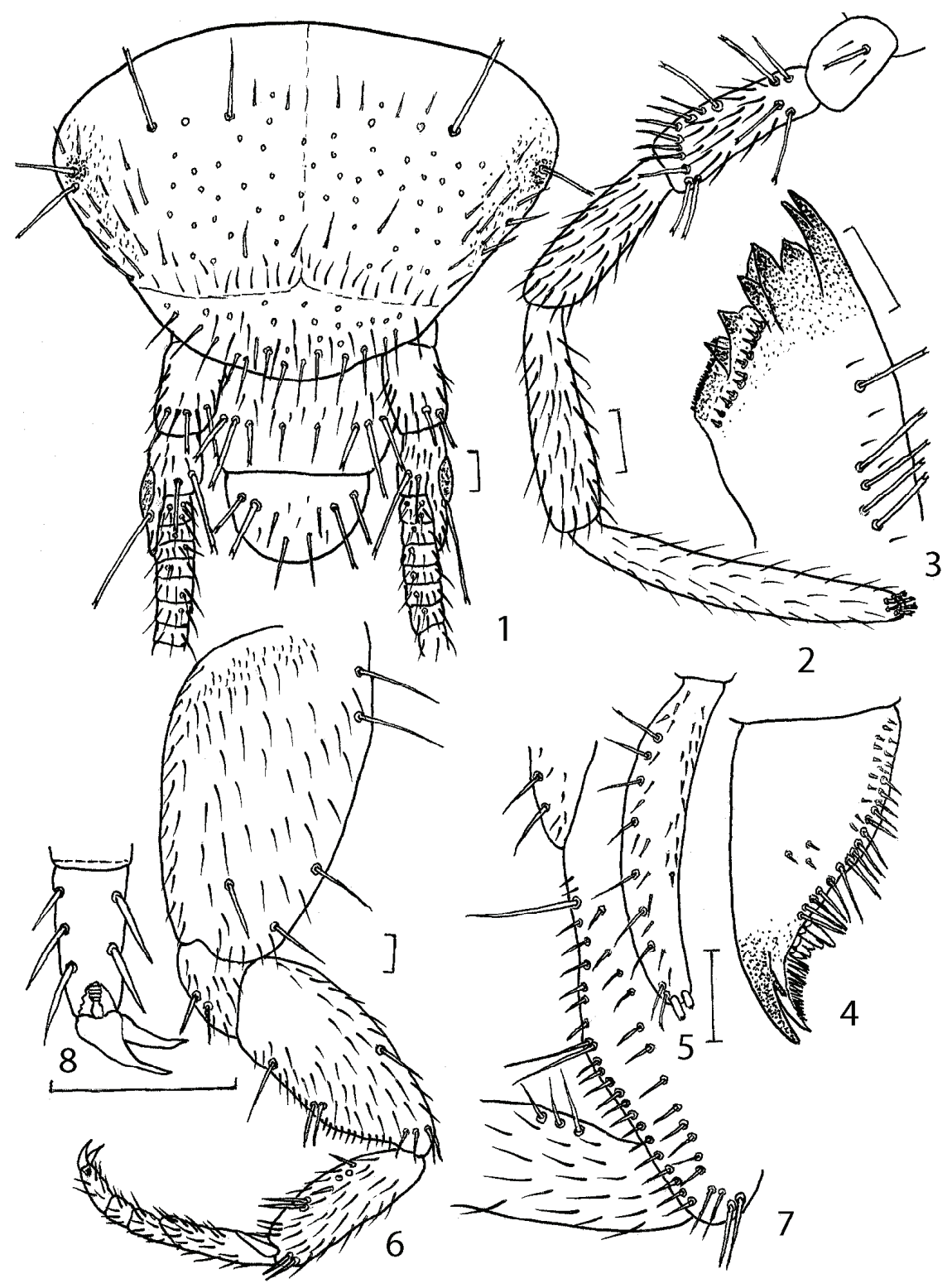

Figs 1-8. Allobrinckina belousovi Kaplin, sp. n., holotype $\delta$ : $1-$ head capsule with clypeus, labrum, antennae (scapus, pedicellus with apophyses, basal part of flagellum); 2 maxillary palp; 3 - distal part of mandible; 4 - galea of maxilla; 5 - lacinia of maxilla; 6 fore leg; 7 - inner ventral part of fore femur; 8 - hind pretarsus and 3rd tarsomere. Scale bars $=0.1 \mathrm{~mm}$. 


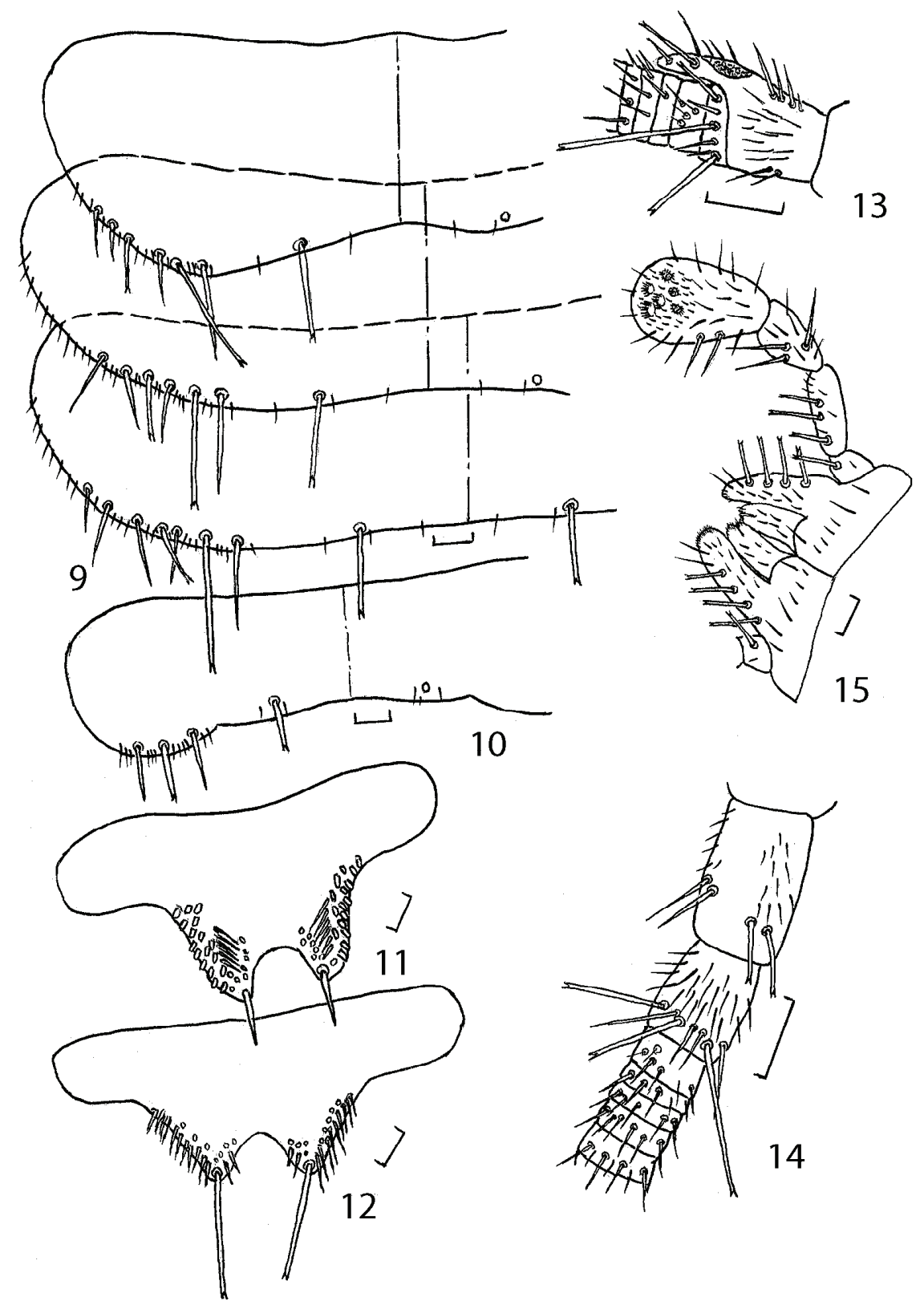

Figs 9-15. Allobrinckina belousovi Kaplin, sp. n., holotype $\widehat{o}(9-11,13,15)$, paratype $\bigcirc$ (12, 14): 9 - urotergites I-III; 10 - urotergite IX; 11, 12 - urotergite X; 13 - pedicellus with apophyses and fovea; 14 - scapus, pedicellus and basal part of flagellum; 15 - labial palp and ligula. Scale bars $=0.1 \mathrm{~mm}$. 
female and male of Allobrinckina gen. n. divided into two lobes as in Squamatinia. Male pedicellus of Allobrinckina gen. n. with well-developed apophyses and fovea. Among Nocoletiidae fovea also described only in males of Lepidospora and Brinckina (Mendes, 1994).

ETYMOLOGY. The new genus is named after its probable closeness to Pseudobrickina Mendes, 2002.

Allobrinckina belousovi Kaplin, sp. n.

http://zoobank.org/NomenclaturalActs/1961A916-6B4E-47C1-99E5-D7FEB96006BD

Figs $1-25$

MATERIAL. Holotype - $\hat{\jmath}$, China: Yunnan province, NW Lijiang, W Yangtze,

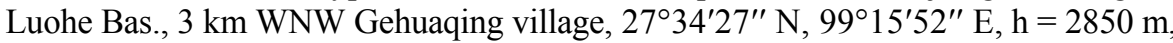
broadleaf forest, near a small river with a stone channel, 06 VI 2018, leg. I. Belousov, I. Kabak (VIZR) (in slides). Paratypes -2 q, same locality, data and leg., as for holotype (VIZR) ( $1 \%$ in slides; $1 \%$ in $75 \%$ alcohol).

DESCRIPTION. Body length of male $7.6 \mathrm{~mm}$, female $6.5-8.4 \mathrm{~mm}$, head width 1.4-1.5 mm; thorax width $1.6-1.7 \mathrm{~mm}$; urite IX width $0.7-0.8 \mathrm{~mm}$.

Appearance whitish in color, chaetae and scales golden, light golden; mesochaetae and most macrochaetae simple, without an apical bifurcation; some of the longer macrochaetae with apical bifurcation. Pigment lacking. Scales multi-radiate with about 14-18 rays covering body (thoracic tergites, urotergites, urosternites, subgenital plate, coxae) but lacking on head and its appendages, tarsi, tibiae and femora of legs, styli, cerci and median dorsal appendage, ovipositor. Antennae broken in all specimens but at least two thirds head and body. Eyes and ocelli absent.

Head male and females 1.3-1.4 times as wide as long; with numerous setae and several long simple and apically bifurcate macrochaetae in lateral part (Fig. 1). Clypeus with transverse row of eight setae, the outer six setae being apically bifurcate. Labrum with similar transverse row of six setae, the outer four setae being apically bifurcate, in posterior part of labrum also two simple setae in both sexes. Antennae elongate, scape of female and male 1.5-1.6 times as long as wide, with one row of six simple macrochaetae in the posterior ventral part and also with several irregular more small setae. Pedicellus of male with relatively long finger-shaped apophyses on medial face surfpassing the middle of the 3rd flagellar division, about 3.3 times longer than wide (Fig 13). Dorsal surface of apopohyses with several long and medium setae. Pedicellus of male also with well-developed ventrally fovea with numerous short setae within. Ratio length of fovea to length of apophyses about 0.8 , width of fovea to width of apophyses about 0.7 . All flagellar divisions with one row of mainly simple macrochaetae. Posterior part of male and female pedicellus with 5-7 macrochaetae, 3 of them long with apical bifurcation (Figs 13, 14). Dorsal surface of apophyses with one long macrochaetae with apical bifurcation. Divisions of male flagellum with three types of sensillum. First flagellar division with 6 , the following four with 2 , the next 14 divisions with $0-2$ trichobothriae. 4th-15th divisions of the flagellum with 0-2 campaniform sensilla. 8th-15th divisions with 
$0-1$ rhabdoid sensilla. Number and distribution of macrochaetae and trichobotriae from the divisions of female flagellum as in male. Divisions of female flagellar probably without campaniform and rhabdoid sensilla.
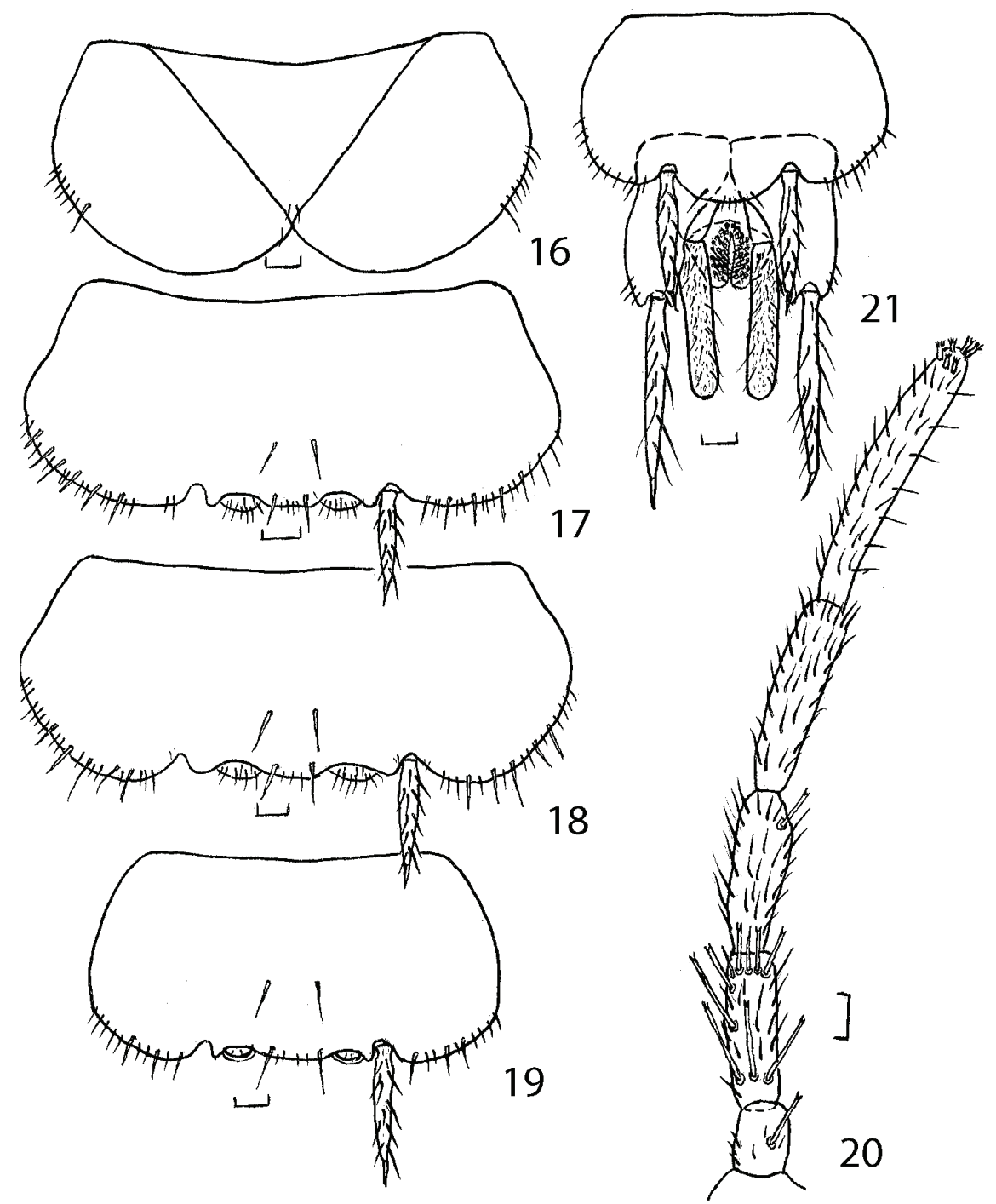

Figs 16-21. Allobrinckina belousovi Kaplin, sp. n., holotype $\widehat{\jmath}(16-19)$, paratype $\odot$ (20): 16 - urosternite and urocoxites I; 17, 18, 19 - urosternites II, III, VII, respectively; 20 maxillary palp; 21 - urosternite VIII, urocoxites IX, penis and parameres. Scale bars $=0.1 \mathrm{~mm}$. 
Mandibles strong with well-developed molar and incisor regions and with external longitudinal row of 5-7 apically bifurcate macrochaetae. Incisor region with 7 incisives (Fig. 3). Around molar area about 20 small conical setae in both sexes. Maxillae of usual form, galea about the same length as the lacinia or slightly shorter with two apical conules (Fig 4); lacinia sclerotized with two apical teeth; pectinate prostheca with about 20-22 narrow projections, 5 rounded apically bifurcate lamellae, first of them is perpendicular, the rest are inclined and about 16-21 setae along margin in both sexes (Fig 5). Maxillary palp long with ultimate palpomere about 6.5 in female and 7.3 in male times longer than wide and 1.4-1.5 times longer than the penultimate palpomere, ultimate palpomere with six papillae of usual form (Figs 2, 20). Second palpomere with subapical ring of strong apically bifurcate macrochaetae and 4-5 such chaetae in the anterior part of palpomere in both sexes. Labium wider than long. Each glossa with three relatively short and several small simple setae; its apical part divided into two lobes (Figs 15, 23). Paragossa with about ten medium and long setae, half of them apically bifurcate and several small setae. Ultimate palpomere of labial palps is about 1.6-1.7 times longer than wide with six papillae of usual type; the penultimate palpomere with 3-4 very long strong simple setae in both sexes.

Length of thorax about one quarter of body, not wider than the abdomen. Ratio width to length of pronotum 1.92, mesonotum 2.06 and metanotum 2.22 in male and respectively 2.03, 2.16 and 2.23 in female (Fig 22). Mesonotum 1.04-1.05 times longer than pro- and metanotum in both sexes. Mesonotum 1.12 and 1.07 times wider than metanotum in male and female respectively. Anterior margin of pronotum with a numerous small setae and with 2-5 + 2-5 sublateral medium macrochaetae, 1-2 posterior of them apically bifurcate. Posterior margin of all thoracic tergites with $1+$ 1 submedian and $2+2$ sublateral macrochaetae. Submedian and $1+1$ inner sublateral macrochaetae apically bifurcate. Lateral margin of these tergites with 3-4+ 3-4 macrochaetae in male and $3+3$ in female. First of them very long and apically bifurcate. Ratio length of this macrochaetae to length of pronotum about 0.36 , mesonotum 0.38-0.42, metanotum 0.40-0.45.

Legs quite elongate. Coxae and femur of male and female widened (Fig 6). Ratios of length to width of coxae, femur, tibia and tarsus as given in Table 1. Legs becoming increasingly long from PI to PIII. Ratio of tarsus length PIII to PI $=1.44$ in male and 1.55 in female; tibia $=1.40$ and 1.49 , femur $=1.10$ and 1.20 , $\operatorname{coxa}=1.20$ and 1.20 , respectively. Coxae with relatively numerous scales and four long apically bifurcate macrochaetae along the outer margin also with one more small and thing apically bifurcate macrochaeta in posterior part of coxa in both sexes. Femur with several macrochaetae, also with row of little spines along inner ventral surface in both sexes (Fig 6). Ventral margin of tibia with several simple macrochaetae. Tarsi with four tarsomeres the basal one as long as about 0.40 (outer margin) or 0.55 (inner margin) of its total length on PIII in both sexes; each tarsomere with two rows of stout macrochaetae along its ventral surface. Praetarsus with two strong claws covered by microtrichia on their basal half, without medial empodial claw. Between claws instead of the empodium there is a slightly convex support oval platform with 5-6 transverse ribs in both sexes (Fig 8). 
Table 1. Ratios of length to width of main leg segments of Allobrinckina belousovi sp. n.

\begin{tabular}{l|c|c|c|c|c|c}
\hline \multirow{2}{*}{ Segments } & \multicolumn{6}{|c}{ Legs } \\
\cline { 2 - 7 } & \multicolumn{3}{|c}{ Male (holotype) } & \multicolumn{3}{c}{ Female } \\
\cline { 2 - 7 } & fore & middle & hind & fore & middle & hind \\
\hline Coxa & 1.9 & 1.8 & 1.7 & 1.9 & 1.9 & 1.8 \\
\hline Femur & 2.2 & 2.0 & 2.3 & 2.2 & 2.0 & 2.3 \\
\hline Tibia & 3.0 & 3.2 & 3.6 & 3.4 & 3.6 & 4.1 \\
\hline Tarsus & 7.9 & 9.2 & 11.4 & 8.0 & 8.6 & 12.0 \\
\hline
\end{tabular}

Urotergites I-IX with $1+1$ submedian, urotergites I-V with $6-8+6-8$, VIVII with 5-6 +5-6 in male and $3+3$ in female, VIII-IX with $3+3$ in male and female sublateral and lateral macrochaetae (Figs 9, 10). Sudmedian and 1-2 + 1-2 sublateral macrochaetae apically bifurcate. Urotergite $\mathrm{X}$ trapezoidal with welldeveloped rounded posterior emargination. Ratio width of posterior base of this urotergite to depth of its emargination about 2.1 in female and 1.6 in male (Figs 11, 12). Posterolateral corners of urotergite $X$ with $1+1$ apical macrochaetae. These macrochaetae in female long and apically bifurcate and in male more short and simple. Ratios of lengths of macrochaetae and urotergite $\mathrm{X}$ about 0.67 in female and 0.35 in male. Urotergite $X$ of male with $16+17$ lateral pegs and with simple macrochaetae, $6+6$ of them form two longitudinal rows near the inner part of pegs areas. Outer and inner margin of projections of urotergite $\mathrm{X}$ in female with simple macrochaetae.

Table 2. Length and width ratios of urosternites, urocoxites and styli of Allobrinckina belousovi sp. $\mathbf{n}$.

\begin{tabular}{|c|c|c|c|c|c|c|}
\hline \multirow{3}{*}{ Urite } & \multirow{2}{*}{\multicolumn{2}{|c|}{$\begin{array}{l}\text { Width / length of } \\
\text { urosternite }\end{array}$}} & \multicolumn{4}{|c|}{ Length ratios } \\
\hline & & & \multicolumn{2}{|c|}{$\begin{array}{c}\text { Stylus (not including apical } \\
\text { spines) / urosternite or urocoxite }\end{array}$} & \multicolumn{2}{|c|}{$\begin{array}{c}\text { Apical spine / } \\
\text { stylus }\end{array}$} \\
\hline & male & female & male & female & male & female \\
\hline II & 2.46 & 2.28 & 0.40 & $?$ & 0.22 & $?$ \\
\hline III & 2.52 & 2.36 & 0,47 & 0.48 & 0.21 & 0.26 \\
\hline IV & 2.64 & 2.42 & 0.48 & 0.49 & 0.21 & 0.24 \\
\hline $\mathbf{V}$ & 2.24 & 2.35 & 0.48 & 0.52 & 0.20 & 0.22 \\
\hline VI & 2.21 & 2.35 & 0.55 & $?$ & 0.20 & $?$ \\
\hline VII & 2.00 & 1.93 & 0.64 & $?$ & 0.20 & $?$ \\
\hline VIII & 1.63 & - & 0.68 & 0.85 & 0.20 & 0.23 \\
\hline IX & - & - & 1.06 & 0.85 & 0.16 & 0.17 \\
\hline
\end{tabular}

Urosternite I divided into a median sternite and two lateral coxites (Fig 16). Urosternites II-VII in female and II-VIII in male entire, styli on urosternites II-IX, $1+$ I eversible vesicles on urosternites II-VI and $1+1$ pseudovesicles on urosternite VII (Figs 17-19, 21, 25). Posterior angle of urosternite I about $83^{\circ}$ in male and $74^{\circ}$ in female with two thing simple setae. Ratios of lengths and widths of urosternites and urocoxites given in Table 2. Posterior part of urosternites II-VII with two pairs 
of relatively long and thin apically bifurcate setae between eversible vesicles. Sublateral margin of urosternites with numerous long and relatively short simple setae. Subgenital plate in female well-developed, suboval (Fig 24). Ratio length to width of subgenital plate about 0.76 .
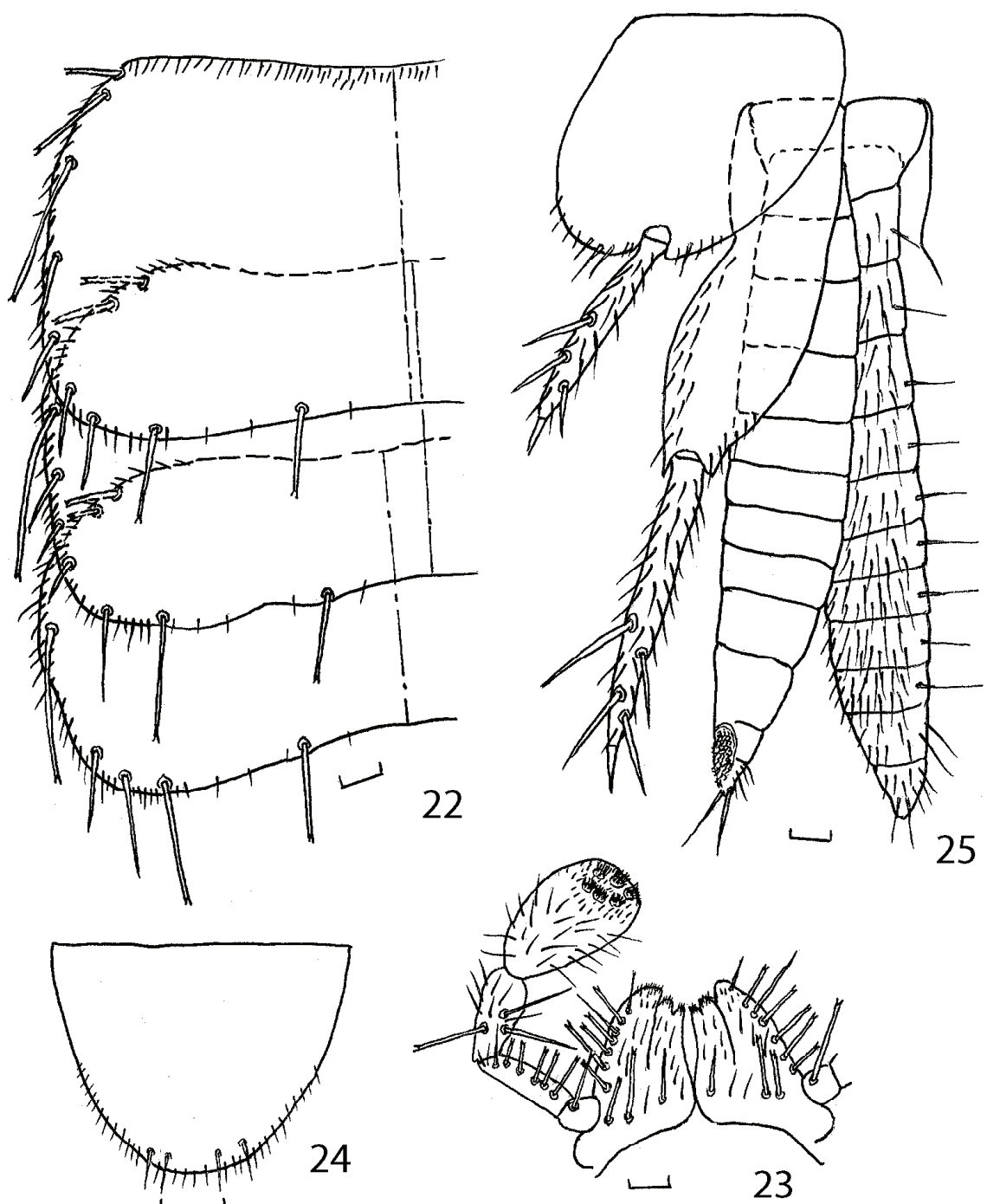

Figs 22-25. Allobrinckina belousovi Kaplin, sp. n., holotype $\widehat{\partial}$ (22), paratype $\odot$ (23-25): 22 - pro-, meso- and metanotum; 23 - labial palp and ligula; 24 - subgenital plate; 25 urocoxites VIII and IX, anterior and posterior gonapophyses. Scale bars $=0.1 \mathrm{~mm}$. 
Parameres reach to about 0.55 the length of styli, with several setae along their length and some small apices setulae. Paramera about six times longer than wide. Penis reachs to about 0.35 the length of parameres (Fig 21). Ovipositor slightly longer than styli IX, gonapophyses with 11-12 divisions (Fig 25). Cerci and caudal filament of male brouken. First basal divisions of cerci with $1+1$ preserved inner pegs. Basal divisions of female cerci with 2-6, caudal filament with 1-4 trichobothriae.

ETIMOLOGY. The new species is named after I. Belousov (VIZR), one of the collectors of this species.

\section{ACKNOWLEDGMENTS}

The author expresses sincere gratitude to I. I. Kabak and I. A. Belousov (VIZR) for the collections of bristletails from China supplied for examination.

\section{REFERENCES}

Escherich K. 1905. Das System der Lepismatiden. Zoologica [Stuttgart], 18 (1/2) (Heft 43): $1-164$.

Espinasa L. \& Mendes, L.F. 2013. The first cavernicolous Nicoletiidae (Insecta: Zygentoma) from the United Arab Emirates. Journal of Cave and Karst Studies, 75(2): 121-125. DOI: $10.4311 / 2011$ LSC0256

Kaplin, V.G. 2012. On the Fauna of the Bristletail Family Nicoletiidae (Thysanura) of Thailand. Zoologicheskii Zhurnal, 91(5): 544-553 [In Russian; English translation: Entomological Review, 2012. 92(9): 966-976. DOI: 10.1134/S0013873812090023]

Mendes, L.F. 1988. Sur deux nouvelles Nicoletiidae (Zygentoma) cavernicoles de Grèce et de Turquie et remarques sur la systématique de la famille. Revue Suisse de Zoologie, 95(3): 751-772. https://archive.org/stream/biostor-117151/biostor-117151_djvu.txt

Mendes, L.F. 1994. Evolutionary relationships among the Nicoletiidae (Insecta, Zygentoma). Acta Zoologica Fennica, 195: 98-103.

Mendes, L.F. 2002a. New species and new data on Protrinemuridae and Nicoletiidae (Zygentoma) from Eastern Asia and Pacific islands. Annales de la Société Entomologique de France, 38(4): 399-433. DOI: 10.1080/00379271.2002.10697352

Mendes, L.F. 2002b. Some new data and descriptions of thysanurans (Zygentoma: Nicoletiidae) from Central and Eastern Africa. Annales Musée Royal de l'Africue Centrale. Série in Octavo. Sciences Zoologiques, 290: 87-127.

Molero, R., Bach, C., Sendra, A., Montagud, S., Barranco, P. \& Gaju, M. 2013. Revision of the genus Coletinia (Zygentoma, Nicoletiidae) in the Iberian Peninsula, with descriptions of nine new species. Zootaxa, 3615(1): 1-60.

Paclt, J. 1974. Neue Beiträge zur Kenntnis der Apterygoten-Sammlung des Zoologischen Staatsinstitut und Zoologischen Museums Hamburg. IV. Epigäische Nicoletiidae (Thysanurta). Entomologische Mitteilungen aus dem Zoologischen Museum Hamburg, 4(89): 543-549, Hamburg. https://www.zobodat.at/pdf/Ent-Mitt-Zool-Mus-Hamburg_4_05430549.pdf

Reboleira, A.S., Gonçalves, F., Oromí, P. \& Mendes, L.F. 2012: Squamatinia algharbica gen. n. sp. n., a remarkable new Coletiniinae silverfish (Zygentoma: Nicoletiidae) from caves in southern Portugal. Zootaxa, 3260: 33-46. DOI: 10.5281/zenodo.209789

Smith, G.B. 1998. Review of the Australian Nicoletiinae (Zygentoma: Nicoletiidae). Invertebrate Taxonomy, 12: 135-189. 
Smith, G.B. \& McRae, J. 2016. Further short endemic troglobitic silverfish (Zygentoma: Nicoleniidae; Subnicoletiinae and Coletiniinae) from north-western Australia. Records of the Western Australian Museum, 31(1): 41-55. DOI: 10.18195/issn.0312-3162.31(1).2016. 041-055

Tahami, M.S., Molero, R., Gaju, M. \& Sadeghi, S. 2018. Discovery of representatives of the family Nicoletiidae (Insecta: Zygentoma) from caves of Iran, with descriptions of two new supraspecific taxa. Zootaxa, 4369(2): 253-269. DOI: 10.11646/zootaxa.4369.2.6

Wygodzinsky, P. 1955. Thysanura. P. 83-190. In: B. Hanström, P. Brinck and C. Rudebeck (Eds). South African Animal Life, Results of the Lund University Expedition in 19501951: Almqvist \& Wiksell, Stockholm, Sweden, 2.

Wygodzinsky, P. 1980. A Survey of the Nicoletiinae of Europe (Nicoletiidae, Thysanura, Insecta). American Museum Novitates, 2695: 1-24. DOI: http://hdl.handle.net/2246/5428 